\title{
Classification of Fixtures For Assessment
}

\author{
John W. Holmes*
}

JUDGES have toiled for centuries to fit round bits of human property into two square holes labeled "land" and "goods." Much practice has lent them a certain facility in this odd task, yet two recent decisions of the Supreme Court of California demonstrate anew that the ancient puzzle of what constitutes a "fixture" continues to bedevil the law. ${ }^{1}$ Both cases involved disputes between taxpayer and assessor over the question: When does property, originally chattel in character and still retaining its movability, become so identified with the real estate to which it has been annexed as to become assessable for taxation as part of the realty?

The question demands a reasoned answer because it probes the taxpayer's pocketbook. Due to the prevalence of "special assessments" to defray the cost of public improvements undertaken in former flush times, it frequently is the taxpayer's desire that his property be assessed as personalty rather than as part of the real estate, since personal property is not generally subject to such levies. Again, trade fixtures are assessable to the tenant if they are regarded as personalty, but to the lessor if improvements to real estate. Cities acquiring lands or improvements outside their municipal limits may be taxed if the property was subject to taxation when acquired, but not if such property is classified as personalty. ${ }^{2}$ These and similar situations ${ }^{3}$ demand

* Member of Los Angeles bar; A.B. 1926, LL.B. 1928, University of Michigan; author of legal articles in various publications.

The author is indebted to Henry C. Ramsey, Deputy City Attorney, City of Los Angeles, for valuable aid in the preparation of this article.

${ }^{1}$ San Diego Trust \& Savings Bank v. County of San Diego (Aug. 26, 1940) 100 Cal. Dec. 244, 105 P. (2d) 94, reli'g den., Sept. 25, 1940; Southern Cal. Tel. Co. v. State Board of Equalization (1938) 12 Cal. (2d) 127, 82 P. (2d) 422 . It has been suggested that the classification of all property as either real or personal is "artificial" and that a fixture "does not fit naturally and inevitably into either classification." Miles, The Intention Test in the Law of Fixtures (1934) 12 N. Y. U. L. Q. Rev. 66, 87. Contrary holdings by different trial courts in the same state as to the proper classification of the same property have been upheld on the ground that reasonable minds may differ as to its character as real or personal. Commercial Credit Corp. v. Commonwealth Mtge. etc., Co. (1931) 276 Mass. 335, 340, 177 N. E. 88, 90. Cf. Commercial Credit Corp. v. Gould (1931) 275 Mass. 48, 175 N. E. 264.

2 CaL. Const. art. XIII, $\S 1$.

3. It is important in California that all property of banks be classified properly and uniformly as real or personal, since only real property of banks is subject to property taration. CaI. Const. art. XIII, §16; Rev. Stat. (1878) §5219 as amended 44 Stat. (1926) 223,12 U.S. C. (1934) §548. 
that the classification for tax purposes of that borderline species of property known as "fixtures" be made in accordance with defensible principles capable of uniform application.

Formidable difficulties greet the searcher after such principles. "Fixtures" are hermaphrodites in the law. It is said they are things ". . o originally chattel in their nature, which are so fixed or annexed, either actually or constructively, to the realty, as to have lost, either wholly or to some extent, and for some purposes, while so annexed, their character as movable chattels." 4

The interstices of the definition suggest the uncertainties confronting the assessor. How is he to determine whether machinery im a factory, or an electric transmission line, or other such "borderline" property, has "lost its character" as a chattel to an "extent" that will justify its classification as part of realty for the purpose of taxation?

\section{THE RULE OF INTENTION}

After many vicissitudes the law now is settled that in private transactions the legal character of annexed property depends upon the intention of the annexor. ${ }^{5}$ If the person annexing chattels to real estate intends them to become a permanent accession to the realty, they are fixtures and part of the realty in the eyes of the law. To the contrary, if the annexor's intention is that annexation shall be temporary.

Intention of the annexor being the touchstone, means for ascertaining that intention are of primary importance. The legal intention of permanence is not the subjective, unexpressed or secret purpose of the annexor ${ }^{6}$ it is the intention which the annexing party has made palpable, either by expressly declaring it in approved form, ${ }^{7}$ or by

4 Eweir, A Treatise on the Law of Fixtures (2d ed. 1905)*6.

5 Teaff v. Hewitt (1853) 1 Ohio St. 511, 59 Am. Dec. 634, is the leading case expressing the modern doctrine of fixtures. The soundness of the rule of intention when applied in certain relationships, such as that of landowner-trespasser, and landowner-licensee, has been questioned (Miles, op. cit. supra note 1), but the rule has general acceptance. See Brown, Personal Property (1936) § 137; EweIx, op. cit. supra note 4, at *22,*89.

6 Gosliner v. Briones (1921) 187 Cal. 557, 204 Pac. 19; San Diego Trust \& Savings Bank v. County of San Diego, supra note 1; Beebe v. Pioneer Bank \& Trust Co. (1921) 34 Idaho 385, 201 Pac. 717; Cornell College v. Crain (1931) 211 Iowa 1343, 235 N.W. 731; Hopewell Mills v. Taunton Sav. Bank (1890) 150 Mass. 519, 23 N. E. 327 ; Frost v. Schinkel (1931) 121 Neb. 784, 238 N. W. 659, (1932) 77 A. L. R. 1381; Teaff v. Hewitt, supra note 5; State ex rel. Gisholt M. Co. v. Norsman (1919) 168 Wis. 442, 169 N.W. 429.

7 Oakland Bank of Sav. v. California Pressed Brick Co. (1920) 183 Cal. 295, 191 Pac. 524; San Diego Trust \& Savings Bank v. County of San Diego, supra note 1; Southern Cal. H. \& M. Co. v. Borton (1920) 46 Cal. App. 524, 189 Pac. 1022 ; Ford v. Cobb (1859) 20 N. Y. 344; Tifft v. Horton (1873) 53 N. Y. 377, 13 Am. Rep. 537; Teaff v. Hewitt, 
entering into such relationship to the realty and its owner and so dealing with the annexed property that his intention may be inferred from those circumstances. ${ }^{8}$

Intention of permanence, then, may be express or implied. When the intention is expressed in private agreements, it is binding as between the parties; but such agreements do not defeat the rights of third parties not privy thereto who are without notice. ${ }^{9}$

The indicia by which implied intention of permanence may be inferred are said to be: "the nature of the article affixed, the relation and situation of the party making the annexation, the structure and mode of annexation, and the purpose or use for which the aumexation has been made." 10 That is to say, if the annexed property is of such character that its permanent accession to the realty is customary, or its physical attachment is by means which commonly denote relative permanence of annexation, ${ }^{11}$ or if the usefulness of the annexed property in connection with the particular land is likely to be of long or mdefinite duration, ${ }^{12}$ these circumstances together or simgly will support an inference that the annexation when made was intended to be permanent, unless there be some feature in the relationship of the parties inducing a contrary inference. ${ }^{13}$

USEFULNESS OF THE RULE OF INTENTION IN CLASSIFYING PROPERTY FOR PURPOSE OF ASSESSMENT

(a) Statutes.

What is and what is not a fixture for all purposes, mcluding taxation, frequently is determined by statute. It often happens, also, that the legislature expressly declares some things to be real or personal supra note 5; Workman v. Henrie (1928) 71 Utah 400, 266 Pac. 1033, (1929) 58 A.L.R. 1346; and see cases cited 26 C. J. 676, §39.

8 Teaff v. Hewitt, supra note 5; BRown, op. cit. supra note 5, at $\$ 141$.

9 In re A. E. Savage Baking Co. (D. N. J., 1919) 259 Fed. 976; Oakland Bank of Sav. v. California Pressed Brick Co., supra note 7; Dobschuetz v. Holliday (1876) 82 Ill. 371; Cross v. Weare Comm. Co. (1894) 153 Ill. 499, 38 N. E. 1038; Fletcher v. Kelly (1893) 88 Iowa 475,55 N.W. 474, 21 L. R.A. 347; Frost v. Schinkel, supra note 6; Central Union Gas Co. v. Browning (1913) 210 N. Y. 10, 103 N. E. 822; Workman v. Henrie, supra note 7. The rule apparently is not umiversally followed. 26 C. J. 682, n. 72.

10 Teaff v. Hewitt, supra note 5 at 530,59 Am. Dec. at 645.

11 M. P. Moller, Inc. v. Wilson (1936) 8 Cal. (2d) 31, 63 P. (2d) 818; Snedeker v. Warring (1854) 12 N.Y. 170; People ex rel. National Starch Co. v. Waldron (1898) 26 App. Div. 527, 531-532, 50 N. Y. S. 523, 525; and see Brown, op. cit. supra note 5, at $\S 138$.

12 City of Los Angeles v. Klinker (1933) 219 Cal. 198, 25 P. (2d) 826, (1934) 90 A. L. R. 148; M. P. Moller, Inc. v. Wilson, supra note 11; EwEn, op. cit. supra note 4, **8-32.

13 Tifft v. Horton, supra note 7 at 382, 13 Am. Rep. at 540-541. 
property for the single purpose of taxation. ${ }^{14}$ In such cases, the singling out of specific kinds of property for special treatment for tax purposes may be merely declaratory of what would otherwise be the law, or the effect may be to enforce a classification contrary thereto. Recently, it has been held that a statute fixing the character of a specific kind of property as personalty for general purposes does not foreclose its assessment as part of the real estate if it meets the statutory standard of a fixture. ${ }^{15}$ The authority of the legislature arbitrarily to classify property as real or personal for purposes of taxation has been vindicated. ${ }^{16}$

In the present state of the law, however, statutory fiat plays a minor role in classifying property for purposes of taxation. For this reason, the assessor generally is obliged to resort to general principles and ascertain for himself the annexor's intention. This, it will be recalled, is the same test that determines the status of annexed property as between private parties. It does not follow, however, that the same criteria of intention of permanence have the same weight in classification of amiexed property for tax purposes as in resolving disputes between private persons.

\section{(b) Private Agreements.}

This is particularly true of the part played by private agreements as indicia of intention of permanence of annexation. It was pointed out above that the usefulness of this mode of ascertaining the intention of the parties is sharply limited because such private arrangements do not usually bind third parties without notice: ${ }^{17}$ The assessor is not generally privy to the business transactions of property owners. He has but two means for obtaining reliable information regarding the legal status of annexed property. First, in his work of keeping abreast of market values of assessable property and in keeping current his record of property ownership, he scans recorded real estate transactions. To the extent, therefore, that private agreements are recorded,

14 E.g., IdAHO CODE ANN. (1932) §61-110; IOWA CODE (1939) \$\$6959, 6977; Kan. Gen. Stat. ANN. (Corrick, 1935) \& 79-102; ME. Rev. Stat. (1930) c. 13, \& 3 and c. 87, \& 1; Mo. Laws 1937, p. 545; Nev. CoMr. LAws (Hillyer, 1929) § 6419; N. H. PUB. LaWs (1926) c. 60, §§5-7; NEw YORK TAX LAW (1909) § 2; R. I. Gen. LAWS (1938) c. 30, §§ 2, 3; S. C. Code (1932) § 2577; UTAE REv. Stat. (1933) §80.3.1; VT. PUB. LAWS (1933) \$§584-586.

15 San Diego Trust \& Savings Bank v. County of San Diego, supra note 1.

16 Johnson v. Roberts (1882) 102 Ill. 655; M. K. \& T. Ry. v. Miami County (1903) 67 Kan. 434, 440, 73 Pac. 103, 105.

17 Supra note 9. 
the assessor may be deemed to have notice of them. ${ }^{18}$ Second, in most if not all states, property owners are required to make periodical statements listing their taxable property. To the extent that statutes require this, and insofar as the assessor is justified in relying upon information thus conveyed, the assessor is provided opportunity to know of private agreements respecting the status of annexed property ${ }^{19}$

These means of knowledge, however, leave the assessor without much real aid. Information contained in recorded agreements is of limited value. Leases, for example, will provide that the lessee may remove at the end of the term improvements placed by him on the land, ${ }^{20}$ or that the improvements shall become the property of the lessor, ${ }^{21}$ or that the lessor will pay a fair price for such improvements at the end of the term; ${ }^{22}$ or the lease may be silent on the subject. ${ }^{23}$ Under which, if any, of these circumstances is the assessor to conclude that the lessee "intended" to make annexed buildings a part of the real estate? Is the assessor to decide that because the lessee has the right to remove the buildings when he gives up his tenancy, they are personal property of the lessee today? To so conclude, the assessor may have to ignore such pertinent circumstances as the size and character of the improvement, the nature of its physical attachment to the real estate, the purpose of its use and the actual intention of the lessee when he annexed the property never to remove the buildings but to wear them out in use, or abandon them at the end of his term.

18 Southworth v. Edmands (1890) 152 Mass. 203, 25 N. E. 106. Since his work necessarily involves close watch of recorded property transactions, no good reason appears why the assessor should not take notice of the terms of recorded written agreements affecting the legal character of property. In a number of cases it is held or assumed that the terms of leases respecting the right of the lessee to remove improvements from leased premises are material to the inquiry whether the improvements should be classed as personal or real property for purposes of taxation. See infra notes 27 and 28 .

19 Since the function of the property owner's statement is to convey information, it seems proper that the assessor in classifying the property should be required to heed such facts as are revealed thereby.

20 Parker v. Redfield (1835) 10 Conn. 490; Comstock v. Town of Waterford (1911) 85 Conn. 6, 81 Atl. 1059, (1912) 37 L. R. A. (N. s.) 1166; Boxer v. Sears (1925) 119 Kan. 733, 241 Pac. 443; Milligan v. Drury (1881) 130 Mass. 428; State ex rel. Ziegenhein v. Mission Free School (1901) 162 Mo. 332, 62 S. W. 998; Clove Sprimg Iron Works v. Cone (1884) 56 Vt. 603.

21 People ex rel. Van Nest v. Commissioners (1880) 80 N. Y.573, 574; People ex rel. Muller v. Board of Assessors (1883) 93 N. Y. 308; People ex rel. Intermational Nav. Co. v. Barker (1897) 153 N. Y. 98,47 N.E. 46.

22 Russell v. City of New Haven (1883) 51 Conn. 259; Schoellkopf v. Coatsworth (1901) 166 N.Y. 77, 59 N.E. 710.

23 Matter of Long Beach Land Co. (1905) 101 App. Div. 159, 91 N. Y.S. 503. 
To what extent the law requires assessors to heed private agreements is not clear. In determining who is the owner of property for purposes of taxation assessors are entitled to rely on the record title and need not go behind it to inquire into secret or unrecorded transfers. ${ }^{24}$ Logically, the same principle should apply to the work of classifying property as real or personal. However, the California court has declared, by way of dictum, that the character of the annexation and the use for which the article is designed do not provide a "rule of thumb" applicable by assessors to all cases for determining the intention of the annexor, but that such intention is to be gleaned from "the physical facts, with due consideration to the status 'of the party by whom the articles have been installed."25 The court, however, did not indicate to what extent the assessor must allow the "status" of the annexor to influence his classification. ${ }^{20}$

A few cases have held that an assessor, at peril of an invalid assessment otherwise, must consult the terms of private agreements to ascertain the appropriate classification of annexed property; ${ }^{27}$ and a number of cases have justified the assessor's classification by referring to the terms of private agreements, implying that they are material to the inquiry as to permanence. ${ }^{28}$ To the contrary are other adjudications denying that private arrangements between parties have any weight in determining the status of annexed property for tax purposes. ${ }^{29}$ In recent cases, the California court significantly has not held that equipment installed in leased quarters was personal in character for purposes of taxation merely because of the landlordtenant relationship. Instead, the court has held that installed equipment was properly assessed as part of the real estate, although located in leased premises, where the indicia of intention met the usual tests of a fixture: ${ }^{30}$ cited.

243 Coolex, TaXation (4th ed. 1924) § 1055; 61 C. J. $\$ 773,629$, and cases there

25 Southern Cal. Tel. Co. v. State Board of Equalization, supra note 1, at 135, 82 P. (2d) at 426.

26 Infra note 30.

27 People ex rel. International Nav. Co. v. Barker, supra note 21 ; Buchanan County v. Ritter Lmbr. Co. (1919) 125 Va. 617, 100 S. E. 546.

28 Parker v. Redfield, supre note 20; Russell v. City of New Haven, supra note 22; Boxer v. Sears, supra note 20.

29 Comstock v. Town of Waterford, supra note 20; People ex rel. New York Edison Co. v. Wells (1909) 135 App. Div. 644, 119 N. Y. S. 1057 ; Pennsylvania Stave Co.'s Appeal (1912) $236 \mathrm{~Pa} .97,101,84$ Atl. 761, 762 (statute); Guthrie v. Pittsburgh Dry Goods Co. (1911) $47 \mathrm{~Pa}$. Super. Ct. 384, 389, 401; see Bemis v. Shipe (1904) $26 \mathrm{~Pa}$. Super. Ct. 42.

30 In Southern Cal. Tel. Co. v. State Board of Equalization, supra note 1, the holding was that while nost of the central office equipment located in a modern telephone 
Even between private persons, the status of annexed property is not necessarily determined by reference to its removability under the terms of a contract. Thus, a mortgagee of leased land is entitled to treat trade fixtures on the premises as part of the real estate as between himself and the mortgagor, although the lessee has the right as against both mortgagor and mortgagee to remove the fixtures at will. ${ }^{31}$ There is no reason for the assessor to take the lessee's view rather than that of the mortgagee, or vice versa. In some instances, courts have honored the proposition that annexed property, while annexed, is part of the real estate regardless of what may become its status upon severance. ${ }^{32}$ Thus, nursery stock of a lessee who has the express right to remove it as against his lessor is held nevertheless to be part of the real estate as against a condemnor. ${ }^{33}$ In a tax case, it was held that cotton spinning machinery in a textile mill was part of the real estate for purposes of taxation despite an express

system is properly classified as improvements to real estate under California Political Code section 3617, and Civil Code section 660, nevertheless "In no proper sense can equipment in small leased offices be held an improvement to and part of real property owned by another." $12 \mathrm{Cal}$. (2d) at 138, 82 P. (2d) at 428 . The court noted the fact that the equipment in small leased offices was of comparatively small size and the premises primarily designed for and devoted to purposes other than a telephone office. Therefore, the decision does not stand for the proposition that trade fixtures are personal property for purposes of taxation whenever located in leased premises. While the landlord-tenant relationship doubtless was deemed material, the conclusion seems to have been based rather upon the comparative usefulness of small offices for purposes other than telephone exchanges. This is consistent with the same court's holdings in City of Los Angeles v. Klinker, supra note 12, and M. P. Moller, Inc. v. Wilson, supra note 11 , and is but an application of the same reasoning that led the court to hold the bulk of the telephone office equipment to be improvements to real property. See $12 \mathrm{Cal}$. (2d) at 132-138, $82 \mathrm{P}$. (2d) at 426-428. In San Diego Trust \& Savings Bank v. County of San Diego, sucpra note 1 , at 249,105 P. (2d) at 98 , the court found significance in the fact that banks occupying leased premises had long term leases or, if not, had remained at a fixed location for a long time and bad no intention of moving.

31 Paine v. McDowell \& Tucker (1898) 71 Vt. 28, 32, 41 Atl. 1042, 1044; EwsII, op. cit. supra note 4 , at $* * 278-280$.

32 Merritt v. Judd (1859) 14 Cal. 59; McNally v. Connolly (1886) 70 Cal. 3, 6; San Francisco Breweries v. Schurtz (1894) 104 Cal. 420, 427, 38 Pac. 92, 93; Sprague v. Town of Lisbon (1861) 30 Conn. 18; Russell v. City of New Haven, supra note 22; Comstock v. Town of Waterford, supra note 20; Carr v. Georgia R. R. (1884) 74 Ga. 73, 81; First Nat. Bank of Joliet v. Adam (1891) 138 Ill. 483, 28 N. E. 955 ; Ex parte Makepeace (1848) 31 N. C. 91 ; W. Va. C. \& P. Ry. v. McIntire (1897) 44 W. Va. 210, 28 S. E. 696. See BrowN, op. cit. supra note 5, at \$144; EwELx, op. cit. supra note 4, at *77. But see State ex rel. Cramer v. Bodden (1920) 172 Wis. 64, 178 N.W. 242.

California Civil Code sections 1013 and 1019 seem to imply that trade fixtures wothile affixed are real property; but not all trade fixtures are taxable as real estate, as shown by Southern Cal. Tel. Co. v. State Board of Equalization, supra note 1.

33 City of Los Angeles v. Hughes (1927) 202 Cal. 731, 262 Pac. 737. 
agreement permitting removal at a future time. ${ }^{34}$ At least one court has flatly declared that, regardless of the right of removal of installed fixtures as between lessor and lessee, such property is part of the real estate while affixed, for purposes of assessment and taxation. ${ }^{30}$

The law at its present stage of development is perhaps correctly stated as requiring assessors to take into consideration those private written agreements which normally come to the attention of such officers, either through official recording or by property owners' returns, but does not require that oral agreements and written agreements, the existence or terms of which are in doubt, be sought or examined. ${ }^{36}$ It is to be remembered in this connection that parties to private agreements have the means of enforcing their intentions, either by appropriate provision in their contracts for allocating the tax burden, or by recording their agreements.

\section{(c) Inferred Intention.}

In several states, the effort is made by statute to make more definite the standard of "permanence" which a fixture must satisfy. In such cases, attempts to express the concept of permanence by example-as, for instance, by declaring that a thing is a fixture if "permanently attached to what is thus permanent, as by means of cement, plaster, nails, bolts, or screws"37_have not been regarded as definitive by the courts, which regard the enumerated means of attachment only as indicative of permanence and not very persuasive

34 Ex parte Makepeace, supra note 32.

35 Squire \& Co. v. City of Portland (1909) 106 Me. 234, 76 Atl. 679, (1911) 30 L. R. A. (N. s.) 576 .

${ }^{36}$ State ex rel. Cramer v. Bodden, supra note 32 , however, required the assessor to give cognizance to the implied agreement of the lessor under common law to permit a lessee to remove "trade fixtures" at the end of the term. It was held that printing presses and other such equipment in a job printing and publishing plant on leased premises should have been assessed as personal property because they were "trade fixtures" and, therefore, not within the intendment of the word "fixtures" in a statute requiring fixtures to be assessed as real property. Quaere the soundness of this decision in view of the fact that, while affixed, equipment such as that in question is deemed part of the real estate for purposes of condemnation under the power of eminent domain. City of Los Angeles v. Klinker, supra note 12.

37 CAL. Civ. Code $\S 660$ : "A thing is deemed to be affixed to land when it is attached to it by roots, as in the case of trees, vines, or shrubs; or imbedded in it, as in the case of walls; or permanently resting upon it, as in the case of buildings; or permanently attached to what is thus permanent, as by means of cement, plaster, nails, bolts, or screws ..." This section is typical of the legislation in a number of states. 
in the face of other circumstances evidencing a contrary intention. ${ }^{38}$ But these enumerated means of physical attachment may well have a larger part in determining the legal classification of property for purposes of assessment and taxation than for other purposes, since recourse to private agreements as the test in such cases is not always practicable.

The most favored indicia of implied intention of permanence of annexation, for general purposes, are the various circumstances surrounding the use of the property. The question most frequently asked is whether the real property is peculiarly valuable in use because of the continued presence thereon of the annexed property. ${ }^{39}$

Several recent California cases are illustrative. In one, it was held that the multiple presses, limotype machines, and stereotype equipment of a metropolitan newspaper plant were properly included as part of the real estate in a condemnation proceeding because the newspaper plant, as such, would be useless without them. ${ }^{40}$ In another case, the same court held that a pipe organ installed in a residence in such manner as to meet all the other tests of a fixture was nevertheless personal property as between the owner of the residence and the conditional vendor of the organ, because the usefulness of the resicience, as such, was not impaired by its removal.11 In the third case, it was held that the great bulk of the central office equipment of a modern telephone system, consisting of switchboards, cables, relay racks, relays, coils, coil racks, fuse panels, motors, call registers, and similar equipment, is properly assessed as part of the realty for purposes of taxation because it constitutes a complex mass, functioning as a unit im buildings that are specially suited to such use and relatively useless for other purposes. ${ }^{42}$ In the most recent case, bank vault doors are held to be assessed properly as improvements rather than personalty for the reason, among others, that a

38 "This court has recognized the test of intention to make the article a permanent addition to the realty as manifested by the physical facts, and has accepted the character of the annexation and the use for which the article is designed as subsidiary elements employed for the purpose of testing the intention of permanency." M. P. Moller, Inc. v. Wilson, supra note 11 at 37, 63 P. (2d) at 821. See also Gosliner v. Briones, supra note 6 at 559-560, 204 Pac. at 20.

39 City of Los Angeles v. Klinker, supra note $12 ;$ M. P. Moller, Inc. v. Wilson, supra note 11; Walker Dishwasher Corp. v. Medford Trust Co. (1932) 279 Mass. 33, 180 N. E. 517, 81 A. L. R. 1437; Frost v. Schinkel, supra note 6 ; Pennsylvama Choc. Co. v. Hershey Bros. (1934) 316 Pa. 292, 175 Atl. 694, (1935) 99 A. L. R. 139.

40 City of Los Angeles v. Klinker, supra note 12.

41 M. P. Moller, Inc. v. Wilson, supra note 11.

12 Southern Cal. Tel. Co. v. State Board of Equalization, supra note 1. 
bank vault would not be able to fulfill its function without this special kind of door. ${ }^{43}$

The judges who first evolved this "usefulness" criterion of intention had limited faith in it, ${ }^{44}$ yet it flourishes today more healthily than other indicia of intention..$^{45}$ It has been invoked in a number of tax cases in addition to the two above mentioned. Thus, spinning machinery set up in a textile mill was held to be properly assessed as part of the real estate, smce it was "essential" to the operation of the mill, which clearly was real property. ${ }^{4 B}$ Pipe lines, conduits, and other materials laid in public streets have been held to be personal or real property for purposes of taxation because useful only in connection with property which is denominated personal or real property by statute. ${ }^{47}$

Taxpayers are upon notice, therefore, that the functional approach, giving controlling weight to the usefulness of annexed property in connection with the particular land where located, is much favored and probably will be adopted unless steps are taken to avoid it by registering an unequivocal statement of intention.

\section{CONSTRUCTIVE ANNEXATION}

It frequently happens that among the machinery, appliances and equipment which make useful otherwise barren premises, there is a miscellaneous admixture of articles, some permanently and others impermanently attached, some useful only in the special location

43 San Diego Trust \& Savings Bank v. County of San Diego, supra note 1. at $* 21$.

44 Bartley, C. J., in Teaff v. Hewitt, supra note 5; Ewerr, op. cil. supra note 4,

45 E. g., cases cited supra note 39. In England, where the question has arisen as to the propriety of levies upon real property for the rehef of the indigent, it is held that where the annexed property is "essentially necessary" to the business to which the premises are devoted and "where it is manifest that the machinery is intended to remain connected with the premises as long as they are used for the same purpose," it is properly subject to the levy. Tyne Boiler Works Co. v. Overseers of Longbenton (1886) 18 Q. B. D. 81, 91.

46 Ex parte Makepeace, supra note 32.

47 Shelbyville Water Co. v. People (1892) 140 Ill. 545, 30 N. E. 678, 16 L. R. A. 505; Appeal of the Des Moines Water Co. (1878) 48 Iowa 324; Capital City Gas Light Co. v. Charter Oak Ins. Co. (1879) 51 Iowa 31, 50 N. W. 579; Oskaloosa Water Co. v. Board of Equalization (1892) 84 Iowa 407, 51 N. W. 18, 15 L. R. A. 296; Memphis Gashight Co. v. State (1869) 46 Tenn. 310, (1888) 98 Am. Dec. 452. See also In re Appeal of C. P. R. Tel. Co. (1898) 34 Can.L. J. 789, holding switchboard in a leased telegraph office to be assessable as an improvement because appurtenant to the poles and wires which are defined as improvements by statute; Note (1928) 57 A. L. R. 869. Contra: Providence Gas Co. v. Thurber (1851) 2 R. I. 15, (1884) 55 Am. Dec. 621; Newport Mluminating Co. v. Assessors (1896) 19 R. I. 632, 36 Atl. 426, (1897) 36 L. R.A. 266. 
while others are as useful elsewhere. All machinery of any complexity requires spare parts, special tools, detachable wiring. Part of such property may answer the required tests of permanence while other parts may not. In such cases, the law has recognized the practical futility of attempting separately to classify each item of such property. Where such complicated admixtures of property exist, it is held that the character of all is determined by regarding each item as a part of a single, perfected whole. If that complex unit is so circumstanced as to constitute real property, the miscellaneous items included therein are said to be "constructively" annexed because of their utility as a part of the unit. ${ }^{48}$

The reasons which enforce this view in private controversies are emphasized in the relationship of assessor and property owner. It would not subserve the public good for assessors to fritter away theirtime in speculation over the legal category of a wrench or a crowbar, and it is held that they need not do so. ${ }^{49}$ Again, the functional aspect of annexed property is found to be controlling of its classification.

\section{GENERAI RULES FOR CLASSIFYING PROPERTY AS REAL OR PERSONAI}

FOR PURPOSES OF ASSESSMENT AND TAXATION

From the foregoing considerations, it is possible to suggest some general rules for the guidance of taxpayers and assessors in fixing the proper legal classification of annexed property.

(a) While the law accords to assessors the disputable presumption that their designation of property as real or personal is proper, ${ }^{50}$ the classification adopted in any given case is subject to judicial review and will be overturned unless supported by sound reason.

(b) Taxpayers will do well to express clearly in writing their intention regarding the classification of annexed property as real or personal for purposes of taxation and see to it that such intention is brought home to the assessor, preferably by means of the annual tax-

48 City of Los Angeles v. Klinker, supra note 12; Southern Cal. Tel. Co. v. State Board of Equalization, supra note 1; White v. Cincinnati etc. R. R. (1904) 34 Ind. App. 287, 71 N. E. 276; Consolidated Gas \& Elec. L. \& P. Co. v. Ryan (1934) 165 Md. 484, 169 Atl. 794; Jackson v. State (1914) 213 N. Y. 34, 106 N. E. 758, Ann. Cas. 1916C, 779, L. R.A. 1915D, 492 ; Banner Milling Co. v. State (1925) 240 N. Y. 533, 148 N. E. 668 , (1926) 41 A. L. R. 1019.

49 Southern Cal. Tel. Co. v. State Board of Equalization, supra note 1.

50 In re Maplewood Coal Co. (1904) 213 IIl. 283, 285, 72 N. E. 786, 787; Tunica County v. Tate (1901) 78 Miss. 294, 29 So. 74. 
payers' statement of assessable property. While such statement is not binding on the assessor, in close cases it should be effective.

(c) Having in mind the modifying effect of statutes, administrative regulations, appropriately drawn and recorded agreements between the parties, and property owners' returns, annexed property is part of the real estate for purposes of assessment and taxation:

(i) Except, possibly, in the case of "trade fixtures" of lessees, if the manner of physical annexation to the real estate is such that as between the owner of the real estate and his vendee the annexed property would pass by the conveyance; ${ }^{51}$

(ii) If the manner of physical annexation is such that it may fairly be concluded that the annexed property will remain upon and be used in connection with the real estate for so long as the real estate shall be devoted to the particular use for which the annexed property has special utility, or for such time as it shall be economically feasible to retain the annexed property on the real estate; ${ }^{52}$

(iii) If the annexed property has special usefulness on the particular real estate because of the peculiarly apt location, design or construction of the annexed property for the purposes for which the annexed property is used; ${ }^{53}$

(iv) If the real estate, including improvements, is of special usefulness only in connection with the annexed property. ${ }^{54}$

51 People ex rel. National Starch Co. v. Waldron, supra note 11; Ex parte Makepeace, supra note 32 . The rule as to "trade fixtures" of lessees is in doubt and consideration of the question was expressly reserved by the court in San Diego Trust \& Savings Bank v. County of San Diego, supra note 1. No adjudications have been found treating trade fixtures for tax purposes as personalty or fixtures per se. California Civil Code sections 1013 and 1019 allowing a tenant to remove trade fixtures under stated conditions are not determinative, since they beg the question as to the status of the property during the tenancy. In Southern Cal. Tel. Co. v. State Board of Equalization, supra note 1, the court differentiated clearly between telephone central office equipment on owned premises and that on leased premises, but held that small equipment in small leased quarters should be treated as personalty. The probative facts in cases involving trade fixtures thus apparently are the same as in other cases, and a trade fixture is not ipso facto personalty or fixture. State ex rel. Crainer v. Bodden, supra note 32, looks the other way. A well established presumption supports trade fixtures as personalty. Poole's Case (1703) 1 Salk. 368 ; infra note 56.

52 Ahsolute permanence is not required. M. P. Moller, Inc. v. Wilson, supra note 11 ; Southern Cal. Tel. Co. v. State Board of Equalization; San Diego Trust \& Savings Bank v. County of San Diego, hoth supra note 1.

53 Southern Cal. Tel. Co. v. State Board of Equalization, supra note 1; People ex rel. National Starch Co. v. Waldron, supra note 11; cases cited supra note 47.

54 City of Los Angeles v. Klinker, supra note 12; Southern Cal. Tel. Co. v. State Board of Equalization, supra note 1. 
(d) It is believed that private agreements between persons respecting the status of the property as real or personal are not binding upon assessors unless such agreements are recorded or made part of officially sanctioned taxpayers' statements, and then only if suffciently clear and intelligible as to provide an unambiguous guide to the intention of the annexing party. ${ }^{55}$

(e) "Trade fixtures" which a tenant is entitled to remove at or before the termination of his tenancy are not necessarily classified as personalty for purposes of taxation merely because of the right of removal. If the character of the annexed property, the mode of its annexation, its usefulness on the particular premises, or other circumstances indicate its relative permanence, it is properly assessable as part of the realty; but in the case of trade fixtures, a presumption that the tenant did not intend the annexation to be permanent ${ }^{56}$ must be overcome by sufficient facts to support the contrary conclusion.

(f) Where there is admixture of annexed property, some of which answers the tests of permanence and some of which does not, the proper classification will depend upon whether, viewing all of the said property as a unit, the non-permanently annexed portion may fairly be said to be identified with the part permanently annexed, or whether it has an independent usefulness not necessarily associated with the real estate. ${ }^{57}$

(g) The assessor need not be deterred in making such classifcation as the circumstances reasonably indicate merely because one or more features of the situation may indicate a contrary conclusion. Thus, the fact that the annexed property is carried on the corporate books as personalty, ${ }^{58}$ or that the prescribed system of accounting treats it as personalty, ${ }^{59}$ or that for purposes other than taxation it is defined by statute as personalty ${ }^{60}$ does not overcome "external and visible" circumstances justifying its classification as improvements. ${ }^{61}$

65 Supra notes $29,34,35$, and 36 .

50 "The law presumes that because the interest of a tenant in the land is temporary, that he affixes for himself, with a view to his own enjoyment during his term, and not to enhance the value of the estate ..." Tifft v. Horton, supra note 7 at $382,13 \mathrm{Am}$. Rep. at 540. See CaL. Crv. Code $\$ \S 1013,1019$.

E7 Supra note 48.

E8 City of Los Angeles v. Klinker, supra note 12 ; Beebe v. Pioneer Bank \& Trust Co., supra note 6.

59 Southern Cal. Tel. Co. v. State Board of Equalization, supra note 1.

c0 San Diego Trust \& Savings Bank v. County of San Diego, supra note 1.

61 Circumstances which vindicated assessment of telephone central office equipment located in large offices as improvements to real estate included: (1) the magnitude of the 
The general rules above stated are believed to be substantially the same as those which control the determination of the quantum of property taken in eminent domain proceedings. ${ }^{62}$ They accord, furthermore, with principles applied in controversies between private parties, as, for example, where a tenant has the right as against his lessor to remove trade fixtures, but these articles as between the lessormortgagor and the mortgagee are part of the realty and pass upon foreclosure. ${ }^{.3}$

task of disassembling and reassembling elsewhere; (2) the expense incident to relocation; (3) that the annexed property is essential or convenient to the use of the building for which it was designed; (4) that central office buildings were constructed for the special use; (5) nonsalability of buildings for other purposes than those for which the annexed property is peculiarly fitted; (6) the provision of adjacent land for expansion; (7) the anticipated useful life of the building for its special use; (8) the anticipated useful life of the annexed property; (9) the damage or loss to annexed property if removed; (10) whether the normal course of business requires large-scale removal or alteration of annexed property.

Facts which did not prove impermanence: (1) that removal entails no substantlal injury to the building; (2) that annexed property customarily is used interchangeably with equipment in other offices; (3) that in frequent instances the annexed property actually has been removed; (4) that the prescribed accounting system does not include the annexed property among "permanent fixtures." Southern Cal. Tel. Co. v. State Board of Equalization, supra note 1.

62 City of Los Angeles v. Hughes, supra note 33; City of Los Angeles v. Klinker, supra note 12 ; White v. Cincinnati etc. $R$. R., supra note 48; Matter of the Mayor (1899) 39 App. Div. 589, 57 N. Y. Supp. 657.

63 Supra note 31. 